\title{
Physiological characteristics of hemostasis in piglets after long transport
}

\author{
Lyubov P. Solovyova ${ }^{1 *}$, Andrei L. Kryazhev ${ }^{2}$, Tamara V. Kalysh ${ }^{1}$, and Valery I. Zamuravkin ${ }^{1}$
}

${ }^{1}$ Kostroma State Agricultural Academy, Karavaevo village, Kostroma 156530, Russia

${ }^{2}$ Vologda State Dairy Farming Academy named after N.V. Vereshchagin, Vologda 160555, Russia

\begin{abstract}
Platelets and the clotting system are very sensitive to different harmful environmental impacts. It is noticed that when the action quickly formed hemostasiogram, worsening blood flow in the arterioles and capillaries, which weakens the nutrition and respiration of tissues. Violations of the activity level of hemostasis have a serious economic importance, as it can cause great economic damage by slowing down the processes of growth of productive animals. For this reason, great importance is the reaction of the hemostatic system in piglets is very common for them unfavorable factor of the environment transportation. It occurs when they are transported from breeding farms in different pig farms. Due to the fact that this situation is very common - it creates a need for additional clarification of aspects of the activity changes of parameters of hemostasis that affect perfusion of the organs. It is found that in the case of transport stress in piglets occurs strengthening of the functions of platelets and clotting of blood on the background of decreased activity of fibrinolysis. The emerging situation is the reaction of piglets to the adverse impact from the medium high intensity. As a result of these conditions they are activation of hemostasis and increase the risk of pathology of internal organs.
\end{abstract}

\section{Introduction}

The viability of the organism at any age is highly dependent on the actions of the mass of external and internal factors $[1,2]$. Often the body might result of the impact of the factor of high intensity [3, 4], which can ensure the development of irregularities in his work [5]. This situation stimulates research in medicine $[6,7]$ and in biology $[8,9]$.

In medicine studies of the reactions of the human body have a serious social significance [10] and are designed to ensure search of approaches to increase the average duration of human life $[11,12]$. In biology, these studies particularly on productive animals ensure the preservation of and increased severity of the economic important traits and we have a huge food and economic value $[13,14]$.

It is noticed that the optimum functioning of the whole organism of young growth of any species of productive animals requires optimal feeding of the suitable climate and the complete absence of stress $[15,16]$. In the course of early ontogeny have grown animals not in all cases strictly complied with the required and well-known conditions [17].

As a result, the risk of occurrence of dysfunctions that often leads to disturbances of General condition and decrease in the activity of growth [18]. Recognized that the cause of lowering the viability of the animal is often the deterioration of conditions of blood circulation in internal organs [19-21].
This situation is strongly determined by the development of abnormalities of hemocirculation in the microvasculature, where the metabolic processes [22]. It is known that the success of the microcirculation is essentially determined by the condition of the blood cells [23], and particularly that of platelets [24], is very closely associated with the work of the entire hemostatic system [25].

It was found that platelets and the coagulation system are very sensitive to any negative influences from the environment $[26,27]$. Under these conditions, there is a rapid onset of hemostasiopathy, which disrupts blood flow in small vessels, and a weakening of metabolism in organs [28].

Dysfunctions of hemostasis are of great economic importance due to the possibility of causing serious economic damage due to the inhibition of growth of young productive animals [29].

For this reason, the reaction of hemostasis in piglets to a very common environmental factor, transportation, is of great importance. It takes place during their transportation from large farms to other pig-breeding complexes for breeding and fattening. This situation is very common, which requires its detailed study in terms of changes in the parameters of hemostasis, significant for the perfusion of their organs.

It is known that the normal functioning of all organs of the body very much depends on the level of exposure to it from the external environment and the adequacy of

* Corresponding author: ilmedv1@yandex.ru 
the response to them of the elements that make up the hemostatic system $[30,31]$.

It is clear that the weakening of the functioning of the body occurs under conditions of excessive activation of hemostasis due to a gradual increase in violations of blood rheology and weakening of trophic processes in tissues under these conditions [32]. For this reason, transport stress in piglets should be considered for the possibility of the development of disturbances of excessive hemostasis activity against its background. The goal was set in the work: to trace changes in the activity of hemostasis components in piglets that experienced an episode of transportation.

\section{Materials and methods}

The research is performed in full compliance with the rules of ethics, defined by the European Convention for the protection of vertebrate animals used in experimental and other scientific purposes (adopted in Strasbourg on 18 March 1986 and confirmed in Strasbourg on 15 June 2006).

Under observation are completely healthy pigs belonging to the large white breed, all at the age of 2 months. They moved the episode transport in a closed van from the premises of pig-breeding farms of the Kostroma state agricultural Academy in pig farms located on the territory of Kostroma region of Russia, after selling them for breeding total number of 56 goals. The control group of pigs consisted of 27 healthy pigs two months of age breed: large white, has never endured transportation and stably contained in normal conditions pigsty Kostroma state agricultural Academy.

The study was applied micro-method assessment of platelet aggregation with ADP in the standard concentration [17].

In the work performed was conducted to evaluate the activity of blood coagulation by several factors.
Estimated duration cephalin-kaolin time during the test for activated partial thromboplastin time. Also conducted an assessment of the amount of fibrinogen, recorded the amount of soluble fibrin-monomer complexes in the application of ortofenantrolinom method [33].

In animals, plasma levels were determined inhibitor of tissue plasminogen activator of type 1, using a suitable chromogenic substrate to the test system, Coatest PAI-1 produced by the firm "Chromogenix". The status of the fibrinolytic capacity of the blood was determined using the standard method [33]. Statistical processing of the results of the study conducted using standard statistical software package. The differences were considered significant if $\mathrm{p}<0.05$.

\section{Results and discussion}

The changes in the levels of considered hematological characteristics were found in piglets who experienced an episode of transportation. It was found that the animals that made up the main group had no differences from the level of control in terms of the level of platelets in their blood. Moreover, their ability to aggregate in the main group of piglets with ADP occurs earlier by $33.9 \%$. This was exacerbated by a reduction in the duration of activated partial thromboplastin time (by $29.3 \%$ ). Also, in piglets after the episode of transportation, the level of fibrinogen in the blood was higher than the control by $77.3 \%$, and the fibrinolytic properties of their blood were reduced by $38.2 \%$.

Under these conditions, the concentration of soluble fibrin-monomer complexes was higher than in control animals by $41.5 \%$. These changes were supplemented by a strong increase (by $87.3 \%$ ) in piglets after transportation of the amount of tissue plasminogen activator inhibitor type 1 .

Table 1. Hemostasis rates in observed piglets

\begin{tabular}{|l|c|c|}
\hline \multicolumn{1}{|c|}{ Registrated parameters } & $\begin{array}{c}\text { Control group, } \\
\mathrm{M} \pm \mathrm{m}, \mathrm{n}=27\end{array}$ & $\begin{array}{c}\text { Core group, } \\
\mathrm{M} \pm \mathrm{m}, \mathrm{n}=56\end{array}$ \\
\hline Level platelet, 109/1 & $196.5 \pm 1.33$ & $210.1 \pm 1.62$ \\
\hline $\begin{array}{l}\text { The severity of platelet aggregation in response to } \\
\text { ADP, } \mathrm{s}\end{array}$ & $49.7 \pm 0.34$ & $\begin{array}{c}37.1 \pm 0.29 \\
\mathrm{p}<0.01\end{array}$ \\
\hline $\begin{array}{l}\text { The value of activated partial thromboplastic } \\
\text { time, } \mathrm{s}\end{array}$ & $40.1 \pm 0.53$ & $\begin{array}{c}31.0 \pm 0.43 \\
\mathrm{p}<0.01\end{array}$ \\
\hline The amount of fibrinogen, g/l & $2.2 \pm 0.34$ & $\begin{array}{c}3.9 \pm 0.19 \\
\mathrm{p}<0.01\end{array}$ \\
\hline The level of plasma fibrinolytic activity, min & $7.6 \pm 0.47$ & $\begin{array}{c}5.5 \pm 0.27 \\
\mathrm{p}<0.01\end{array}$ \\
\hline $\begin{array}{l}\text { The level of soluble fibrin-monomer complexes, } \\
\text { mg \% }\end{array}$ & $4.1 \pm 0.34$ & $\begin{array}{c}5.8 \pm 0.42 \\
\mathrm{p}<0.01\end{array}$ \\
\hline $\begin{array}{l}\text { The concentration of tissue plasminogen activator } \\
\text { inhibitor type 1, ng/ml }\end{array}$ & $29.2 \pm 0.48$ & $\begin{array}{c}54.7 \pm 0.75 \\
\mathrm{p}<0.01\end{array}$ \\
\hline
\end{tabular}

Note: $\mathrm{p}$ - significance of differences in indicators between the main and control groups.

It is recognized that increased hemostasis activity accompanies the development of many dysfunctions and pathological processes. This is due to the action of many negative environmental factors. The hemostasiopathy that develops at the same time threatens the development of vasospasm, a violation of hemorheology, which is very dangerous with active growth [34]. 
It is always based on the activation of platelet aggregation and hemocoagulation, which was found out during the examination of piglets that experienced an episode of transportation [35].

The activation of platelet aggregation always worsens their microcirculation processes and is considered as a threat to reduce the level of growth [36]. The revealed increase in hemocoagulation, obviously, occurred due to an increase in the activity of the main number of hemocoagulation factors, which led to increased blood coagulation in both its pathways.

The decrease in the blood of piglets of the mechanisms of fibrinolysis formed serious conditions for micro-thrombosis. An increase in the concentration of fibrinogen in the blood of animals should be considered as one of the mechanisms for stimulating platelet aggregation and enhancing the mechanisms of hemocoagulation. This is due to the fact that it acts as a molecule that binds platelets with each other and a substrate for hemocoagulation, being the main structural basis of a thrombus [37].

It is clear that in the examined piglets there is an intensification of processes in the plasma of lipid peroxidation, which increase the release of $\alpha 2$ antiplasmin into the blood. This situation suppresses fibrinolytic mechanisms of plasma. The resulting imbalance of substances involved in hemostasis formed the basis of hemostasiopathy and worsened the microcirculation processes in all tissues of piglets.

\section{Conclusion}

The normal functioning of the body strongly depends on the nature of the influence on it from the environment and the degree of changes in the activity of the components of hemostasis. In conditions of excessive activation of the components of hemostasis, a violation of the parameters of blood rheology occurs, which worsens trophic organs and tissues.

In the study, it was found that under conditions of transport stress, piglets develop an increase in platelet aggregation and blood coagulation increases with weakening of the mechanisms of fibrinolysis.

The emerging situation is a complex reaction of the organism of these productive animals to the negative impact of a high-intensity environment. This leads to activation of hemostasis in piglets and creates a risk of pathology.

\section{References}

1. S.Yu. Zavalishina, Functioning Of Platelets In Milk And Vegetable Nutrition Calves, Res. J. of Pharmaceut., Biolog. and Chemical Sci., 9(5), 943-949 (2018)

2. A.S. Makhov, I.N. Medvedev, Ensuring The Physiological Optimum Of The Body Using Hydroprocedures, Res. J. of Pharmaceut., Biolog. and Chemical Sci., 9(6), 354-359 (2018)
3. S.Yu. Zavalishina, Functional Properties of Coagulation Hemostasis In Calves During The Phase Of Dairy-Vegetative Nutrition, Res. J. of Pharmaceut., Biolog. and Chemical Sci., 9(5), 784-790 (2018)

4. A.S. Makhov, I.N. Medvedev, Fundamentals Of The Physiology Of The Circulatory System, Res. J. of Pharmaceut., Biolog. and Chemical Sci., 9(6), 453-458 (2018)

5. S.Yu. Zavalishina, Functioning Of Mechanisms Of Hemocoagulation Restriction In Calves At Change Of Methods Of Nutrition, Res. J. of Pharmaceut., Biolog. and Chemical Sci., 9(5), 800-806 (2018)

6. G.S. Mal, E.L. Kharitonov, N.V. Vorobyeva, A.V. Makhova, I.N. Medvedev., Functional Aspects Of Body Resistance, Res. J. of Pharmaceut., Biolog. and Chemical Sci., 9(6), 60-65 (2018)

7. S.Yu. Zavalishina, Deficiency Of Iron As A Cause Of Dysfunction In Calves And Piglets, Res. J. of Pharmaceut., Biolog. and Chemical Sci., 9(5), 978-983 (2018)

8. I.N. Medvedev, Correction of the image of the physical "I" in people with disabilities with hemiparesis who underwent a hemorrhagic stroke, Res. J. of Pharmaceut., Biolog. and Chemical Sci., 9(2), 697-704 (2018)

9. S.Yu. Zavalishina, Functional Properties Of Hemocoagulation In Calves Of Dairy Nutrition, Res. J. of Pharmaceut., Biolog. and Chemical Sci., 9(5), 1016-1022 (2018)

10. A.S. Makhov, I.N. Medvedev, Physiological Basis Of Maintaining The Body's Reactivity, Res. J. of Pharmaceut., Biolog. and Chemical Sci., 9(6), 825-830 (2018)

11. S.Yu. Zavalishina, Physiology of Vascular Hemostasis In Newborn Calves, Res. J. of Pharmaceut., Biolog. and Chemical Sci., 9(5), 1037-1044 (2018)

12. I.N. Medvedev, T.A. Kumova, Angiotensin II receptor inhibitors: role and place in arterial hypertension and metabolic syndrome treatment, Russ. J. of Cardiol., 5, 97-99 (2007)

13. S.Yu. Zavalishina, Functional Properties Of Anticoagulation And Fibrinolysis In Calves Of Plant Nutrition, Res. J. of Pharmaceut., Biolog. and Chemical Sci., 9(5), 1082-1087 (2018)

14. V.I. Maksimov, S.Yu. Zavalishina, A.V. Parakhnevich, E.N. Klimova, N.A. Garbart, A.A. Zabolotnaya, Yu.I. Kovalev, T.Yu. Nikiforova, E.I. Sizoreva, Functional Activity of The Blood Coagulation System Against The Background Of The Influence Of Krezacin And Gamavit In Newborn Piglets Who Underwent Acute Hypoxia, Res. J. of Pharmaceut., Biolog. and Chemical Sci., 9(5), 20372042 (2018)

15. E.S. Tkacheva, S.Yu. Zavalishina, Physiological Features Of Platelet Aggregation In Newborn 
Piglets, Res. J. of Pharmaceut., Biolog. and Chemical Sci., 9(5), 36-42 (2018)

16. S.Yu. Zavalishina, Functional Antiaggregatory Properties Of Blood Vessels In Calves During Transition From Dairy To Plant Type Of Nutrition, Res. J. of Pharmaceut., Biolog. and Chemical Sci., 9(5), 1110-1116 (2018)

17. I.N. Medvedev, A.P. Savchenko, S.Yu. Zavalishina, E.G. Krasnova, T.A. Kumova, O.V. Gamolina, I.A. Skoryatina, T.S. Fadeeva, Methodology of blood rheology assessment in various clinical situations, Russ. J. of Cardiol., 5, 42-45 (2009)

18. S.Yu. Zavalishina, Physiological Features of Vascular Hemostasis In Calves Of Dairy-Vegetative Food, Res. J. of Pharmaceut., Biolog. and Chemical Sci., 9(5), 1137-1143 (2018)

19. E.S. Tkacheva, S.Yu. Zavalishina, Physiology of Platelet Hemostasis In Piglets During The Phase Of Newborns, Res. J. of Pharmaceut., Biolog. and Chemical Sci., 9(5), 1912-1918 (2018)

20. S.Yu. Zavalishina, Functional Features Of Platelets In Newborn Calves With Iron Deficiency, Res. J. of Pharmaceut., Biolog. and Chemical Sci., 9(5), 1153-1158 (2018)

21. A.S. Makhov, I.N. Medvedev, Functional Mechanisms To Ensure The Reactivity of The Organism, Res. J. of Pharmaceut., Biolog. and Chemical Sci., 9(6), 924-929 (2018)

22. S.Yu. Zavalishina, Functional Activity Of Plasma Hemostasis In Neonatal Calves With Iron Deficiency, Who Received Ferroglucin And Glycopin, Res. J. of Pharmaceut., Biolog. and Chemical Sci., 9(5), 1186-1191 (2018)

23. N.V. Vorobyeva, G.S. Mal, S.Yu. Zavalishina, T.I. Glagoleva, I.I. Fayzullina, Influence Of Physical Exercise On The Activity Of Brain Processes, Res. J. of Pharmaceut., Biolog. and Chemical Sci., 9(6), 240-244 (2018)

24. S.Yu. Zavalishina, Physiological Mechanisms of Hemostasis In Living Organisms, Res. J. of Pharmaceut., Biolog. and Chemical Sci., 9(5), 629-634 (2018)

25. E.S. Tkacheva, S.Yu. Zavalishina, Physiological Aspects Of Platelet Aggregation In Piglets Of Milk Nutrition, Res. J. of Pharmaceut., Biolog. and Chemical Sci., 9(5), 74-80 (2018)

26. S.Yu. Zavalishina, Functional Properties of Anticoagulant And Fibrinolytic Activity Of Blood Plasma In Calves In The Phase Of Milk Nutrition, Res. J. of Pharmaceut., Biolog. and Chemical Sci., 9(5), 659-664 (2018)
27. V.I. Maksimov, S.Yu. Zavalishina, A.V. Parakhnevich, E.N. Klimova, N.A. Garbart, A.A. Zabolotnaya, Yu.I. Kovalev, T.Yu. Nikiforova, E.I. Sizoreva, Physiological Dynamics Of Microrheological Characteristics Of Erythrocytes In Piglets During The Phase Of Milk Nutrition, Res. J. of Pharmaceut., Biolog. and Chemical Sci., 9(5), 454-459 (2018)

28. S.Yu. Zavalishina, Physiological Dynamics Of The Blood Coagulation System Activity In Calves During The Phase Of Dairy Nutrition, Res. J. of Pharmaceut., Biolog. and Chemical Sci., 9(5), 680-685 (2018)

29. N.V. Vorobyeva, I.N. Medvedev, Physiological Features Of Platelet Functioning In Calves of Holstein Breed During The Newborn, Res. J. of Pharmaceut., Biolog. and Chemical Sci., 9(6), 129135 (2018)

30. Ju.L. Oshurkova, I.N. Medvedev, Physiological Indicators Of Platelets In Ayrshire Calves During The Dairy Feeding Phase, Res. J. of Pharmaceut., Biolog. and Chemical Sci., 9(6), 171-176 (2018)

31. S.Yu. Zavalishina, Functional Activity Of The Blood Clotting System In Calves During The Phase Of Milk And Vegetable Nutrition, Res. J. of Pharmaceut., Biolog. and Chemical Sci., 9(5), 720-725 (2018)

32. G.S. Mal, N.V. Vorobyeva, A.V. Makhova, I.N. Medvedev, I.I. Fayzullina, Features Of Physical Rehabilitation After Myocardial Infarction, Res. J. of Pharmaceut., Biolog. and Chemical Sci., 9(6), 280-285 (2018)

33. Z.S. Barkagan, A.P. Momot, Diagnosis and controlled therapy of hemostatic disorders (Newdiamed, Moscow, 2008)

34. Ju.L. Oshurkova, I.N. Medvedev, Functional Features Of Platelets In Newborn Calves Ayrshire Breed, Res. J. of Pharmaceut., Biolog. and Chemical Sci., 9(6), 313-318 (2018)

35. T.I. Glagoleva, I.N. Medvedev, Physiological Features Of Anti-aggregational Control Of Blood Vessels Over The Shaped Elements Of Blood In Calves At The Onset Of Ontogenesis, Res. J. of Pharmaceut., Biolog. and Chemical Sci., 9(5), 440-447 (2018)

36. I.N. Medvedev, T.A. Kumova, Valsartan effects on platelet activity in patients with arterial hypertension and metabolic syndrome, Russ. J. of Cardiol., 3, 66-69 (2007)

37. I.N. Medvedev, O.V. Gamolina, Lisinopril effects on platelet activity in patients with arterial hypertension and impaired glucose tolerance, Russ. J. of Cardiol., 3, 45-48 (2008) 